\title{
Trošarinski izdelki v Republiki Sloveniji in primerjava $z$ drugimi državami
}

\author{
UDK: 336.226 .33 \\ Ivan Kopina \\ ivan.kopina@gmail.com \\ Stanka Setnikar Cankar \\ Univerza v Ljubljani, Fakulteta za upravo \\ stanka.setnikar-cankar@fu.uni-li.si
}

IZVLEČEK

Republika Slovenija je 1.5.2004 vstopila v EU. Ob tem je trošarinski sistem nadgradila tako, da je na področju harmoniziranih trošarin $v$ celoti usklajen $\mathrm{s}$ pravnim redom EU. Vstop $\vee$ EU se je odražal tudi na področju pobiranja dajatev, ki postanejo pravica Skupnosti v trenutku knjiženja terjatev v poslovne knjige, država članica pa zadrži 25 \% tradicionalnih lastnih sredstev Skupnosti za stroške pobiranja teh dajatev. Po navedenem dejanju so trošarine postale najpomembnejše dajatve, $k i$ jih $v$ državni proračun vplača Carinska uprava Republike Slovenije. Pri primerjavi stopenj trošarin na trošarinske izdelke med izbranimi državami članicami EU lahko ugotovimo, da Republika Slovenija sodi med države z nižjimi stopnjami trošarin na tobačne izdelke, etilni alkohol in vmesne pijače. Treba bi bilo zvišati predvsem trošarine na tobačne izdelke ter alkohol in alkoholne pijače kar bi prispevalo $k$ povečanju proračunskih sredstev, razlog za zvišanje pa je tudi zdravstveni vidik. Naša država bi lahko sledila zgledu Republike Hrvaške in uvedla trošarine na nekatere neharmonizirane trošarinske izdelke.

Ključne besede: trošarine, harmonizirani trošarinski izdelki, neharmonizirani trošarinski izdelki, trošarinske stopnje, trošarinski sistem, povečanje trošarinskih stopeni

JEL: H21

Kopina, I. \& Setnikar Cankar, S. (2011). Trošarinski izdelki v Republiki Sloveniii in primerjava z drugimi državami. Uprava IX(4), 137-154. 


\section{Uvod}

Trošarinski sistem v Republiki Sloveniii ( $v$ nadaljevanju: Slovenija) se je začel izvajati 1.7.1999. Obsega poseben režim nadzora nad prometom in proizvodnjo trošarinskih izdelkov ter pobiranje trošarin. Upravljanje in izvajanje postopkov $v$ zvezi $s$ trošarinami je $v$ pristojnosti Carinske uprave Republike Slovenije ( $v$ nadaljevanju: carinska uprava), izvajajo pa se $v$ oddelku za trošarine pri posameznem carinskem uradu. Z vstopom Slovenije v EU 1. 5. 2004 se je sistem nadgradil tako, da je na področju harmoniziranih trošarin $v$ celoti usklajen s pravnim redom EU. Osnovo trošarinskega sistema določajo Zakon o trošarinah in njegovi izvedbeni predpisi ter nekatere uredbe na ravni EU, ki se uporabljajo neposredno (Kvenderc, 2008, str. 5).

Leto 2004 je bilo tudi na področju pobiranja dajatev zaznamovano s pridružitvijo Slovenije EU. Carinska uprava je v letu 2004 prevzela nalogo pobiralke tradicionalnih lastnih sredstev Skupnosti. Nijhovo knjigovodsko evidentiranje je kombinacija obračunane in plačane realizacije prihodkov, za razliko od obveznih dajatev, ki so prihodek proračuna Slovenije in se evidentirajo samo po plačani realizaciji. Država članica zadrži $25 \%$ tradicionalnih lastnih sredstev Skupnosti za stroške pobiranja teh dajatev (Carinska uprava RS, 2005, str. 1, 2).

$\checkmark$ članku smo želeli predstaviti dve tezi, in sicer:

a) trošarine so postale $z$ vstopom Slovenije $\vee$ EU najpomembnejše dajatve, ki jih v državni proračun vplača carinska uprava,

b) $\vee$ Sloveniii bi morali spremeniti trošarinski sistem tako, da bo primerljiv z izbranimi državami, in:

- zmanjšati nekatere trošarine,

- uvesti trošarine na nekatere nove izdelke,

- nekatere trošarine zvišati.

\section{Uvedba trošarin v Sloveniji}

Trošarinski sistem se je začel izvajati 1.7.1999, ko so v veljavo stopili Zakon o trošarinah in njegovi izvedbeni predpisi (Košir, 1999, str. 1). 


\subsection{Trošarine}

\subsubsection{Definicija trošarin}

Trošarina ali akciza je davek na porabo določenih izdelkov. Skozi zgodovino se je $v$ strokovni literaturi podajala široka interpretacija koncepta "trošarin". Cnossen (2005, str. 2) v trošarinski sistem uvršča vse izbirne davke na dobrine, storitve in prevozna sredstva. Preece (2008, str. 73) meni, da se izraz "trošarine" nanaša na posredno obliko obdavčenja, ki zajema ozek izbor dobrin (pogosto storitev), ki so po svoji naravi namenjene "prestižu" ali so "potrošniško naravnane".

\subsubsection{Zgodovina trošarin}

Adams (2006, str. 1) meni, da so davki gorivo, ki poganja civilizacijo. Ne poznamo namreč niti ene civilizacije, ki ne bi pobirala davkov.

Trošarinske obdavčitve so se pojavile $v$ 16. in 17. stoletju po zgledu Dancev, ki so davke na pivo, sladkor, sol, alkohol in druge dobrine poimenovali "excijsen". Danskemu zgledu je sledilo veliko germanskih držav, njihovemu uspehu pa je kmalu sledila tudi Anglija s svojimi kolonijami, vključno z ZDA. Na začetku 19. stoletja so $v$ Evropi večino "manjših" trošarin (ki so prinesle malo prihodka) odpravili ali pa jih vključili v splošne davke na dobrine in storitve, "velike" trošarine (na tobačne izdelke, alkoholne pijače in naftne derivate) pa so ostale (Cnossen, 2005, str. 1).

\subsubsection{Razlogi za uvedbo trošarin}

Trošarinski davki so pogosto zaželeni kot nadomestilo za davke državnega proračuna, ki slabo vplivajo na delo in kapital. Čeprav so trošarine včasih imenovane "sirota davčne politike", ima njihova zasnova in dajatve večje posledice, kot večina drugih davkov.

Cnossen (2007, str. 1-2) navaja naslednje razloge za uvedbo trošarin:

- zvišanje proračuna za javno porabo (vse trošarine),

- odraz zunanjih stroškov proizvodnje in porabe, ki niso všteti v ceno (kajenje, popivanje, onesnaževanje),

- odvračanje od uporabe, ki je nezaželena (kajenje, popivanje, kockanje), 
- uporabnina uporabnikov cestnih infrastruktur in vladnih cestnih storitev.

\subsubsection{Usklajevanje trošarin}

Države članice EU imajo različne stopnje, strukture in načine upravljanja trošarin, to pa vpliva na konkurenčnost pod istimi pogoji. Največja razlika med trošarinskimi sistemi je ohranjena s strogim mejnim nadzorom, ki izolira domače trge od tujih carinskih sistemov. Rezultat tega je vpliv medblagovne in meddržavne diskriminacije na trgovanje. Pri presojanju predlogov za uskladitev trošarin je najpomembnejši vpliv na državni proračun. $V$ nekaterih članicah EU trošarine prispevajo več kot $25 \%$ celotnih davčnih in socialnih dajatev. Usklajevanje trošarin v gospodarski skupnosti je primarno namenjeno odstranjevanju omejitev konkurenčnosti fiskalne politike. Za uskladitev davčne politike na skupni osnovi je treba določiti, katere trošarine naj se obdržijo in katere uskladijo. V večini držav obstajajo tri glavne skupine trošarinskih dobrin, in sicer mineralna olja, pridelan tobak in alkoholne pijače. Večina držav, tudi $\vee$ EU, pobere najvišje prispevke za državni proračun od "velike peterice", in sicer od tobačnih izdelkov, piva, alkohola, mineralnih olj in vina. Druge države so uvedle trošarine še na vrsto drugih izdelkov. Poleg davčne osnove se spreminjajo tudi davčne stopnje. Komisija je $v$ tem času izdala številne predloge, večinoma o usklajevanju davčnih struktur, nekaj pa tudi o usklajevanju davčnih stopenj. Počasen napredek pripisujemo vplivu usklajevanja trošarin na državne proračune nekaterih držav članic, kar je izvor konfliktov med državnimi prioritetami in cilji Skupnosti. Po dolgotrajnih pogajanjih so se države članice strinjale s postavitvijo minimalne stopnje kot kombinacije davka na dodano vrednost (ad valorem) in trošarin. Kliub temu so stopnje $v$ državah članicah še vedno zelo različne (Hitiris, 2003, 119-120).

\section{Trošarinski izdelki v Sloveniji}

Zakon o trošarinah (ZTro-UPB8, Uradni list RS, št. 97/10, v nadaljevanju ZTro) določa, da se trošarina plačuje od alkohola in alkoholnih pijač, tobačnih izdelkov ter energentov in električne energije, ki se na območju Slovenije sprostijo $v$ porabo. Trošarina je prihodek proračuna in se plačuje od trošarinskih izdelkov, ki so proizvedeni na območju Slovenije, od trošarinskih izdelkov, ki so vneseni z ozemlja držav 
članic Evropske unije $v$ Slovenijo, in od trošarinskih izdelkov, ki se uvozijo $\checkmark$ Evropsko unijo iz tretjih držav oziroma tretjih ozemeli (ZTro, člen 1-3).

\subsection{Trošarine na tobačne izdelke}

Trošarina se v skladu s 47. členom ZTro plačuje od cigaret, cigar in cigarilosov ter tobaka za kajenje. Trošarinska osnova za tobačne izdelke je 1.000 kosov in drobnoprodajna cena oziroma kilogram izdelka. Trošarina za cigarete se plačuje kot specifična trošarina, ki je določena v znesku za 1.000 kosov, in kot proporcionalna trošarina, ki je določena $v$ odstotku od drobnoprodajne cene najbolj prodajanih cigaret. Znesek specifične trošarine in stopnjo proporcionalne trošarine določi Vlada Republike Slovenije. Sprostitev tobačnih izdelkov v porabo in sprostitev, razen če uvoznik prevaža tobačne izdelke $v$ trošarinsko skladišče ali $v$ prosto carinsko prodajalno, je dovoljeno le, če so tobačni izdelki označeni s tobačno znamko (ZTro, člen 51-52).

\subsubsection{Stopnje trošarin na tobačne izdelke $v$ izbranih državah članicah EU}

$\checkmark$ tabeli 1 so prikazani podatki o stopnjah trošarine za cigarete, cigare in cigarilosi ter drobno rezan tobak, ki so v državah članicah EU veliale na dan 1. 7. 2011.

Za cigarete so imele vse izbrane države članice ( $v$ nadaljevanju: države) predpisano stopnio specifične trošarine in stopnjo proporcionalne trošarine. Najnižjo stopnjo specifične trošarine so imele Italija, Finska in Slovenija, najvišjo pa Irska, Velika Britanija in Nemčija. Najnižjo stopnjo proporcionalne trošarine so imele Velika Britanija, Irska in Romunija, najvišjo pa Italija, Finska in Slovenija. Za cigarilose in cigare je imelo šest držav predpisano specifično stopnjo trošarine, šest držav pa proporcionalno stopnio trošarine. Samo specifično stopnio trošarine so imele štiri države, samo proporcionalno stopnjo trošarine tudi štiri države, medtem ko sta imeli obe stopnji trošarine predpisani dve državi. Najnižjo stopnjo specifične trošarine sta imeli Romunija in Danska, najvišjo pa Irska in Velika Britanija. Najnižjo stopnjo proporcionalne trošarine sta imeli Nemčija in Slovenija, najvišjo pa Finska in Italija. Iz Tabele 1 je še razvidno, da je za drobno rezani tobak imelo osem držav predpisano specifično stopnjo trošarine (za kilogram), štiri države pa proporcionalno stopnjo trošarine (od cene tobaka). Samo specifično stopnjo trošarine je imelo šest držav članic, samo proporcionalno stopnjo trošarine sta imeli 
dve državi članici, obe stopnji trošarine pa sta imeli predpisani dve državi. Najnižjo stopnio specifične trošarine so imele Finska, Slovenija in Nemčija, najvišjo pa Irska, Velika Britanija in Danska. Najnižjo stopnjo proporcionalne trošarine je imela Nemčija, najvišjo pa Italija.

Tabela 1: Stopnje trošarin na tobačne izdelke $v$ izbranih državah EU na dan 1. 7. 2011

\begin{tabular}{|c|c|c|c|c|c|c|}
\hline \multirow[b]{2}{*}{$\begin{array}{l}\text { Država } \\
\text { članica }\end{array}$} & \multicolumn{2}{|c|}{ Cigarete } & \multicolumn{2}{|c|}{ Cigare in cigarilosi } & \multicolumn{2}{|c|}{ Drobno rezani tobak } \\
\hline & $\begin{array}{c}\text { Specifižna } \\
\text { troš. za } \\
1000 \text { kosov } \\
\text { (v EUR) }\end{array}$ & $\begin{array}{l}\text { Proporcio- } \\
\text { nalna troš. od } \\
\text { cene zavoička } \\
\text { cigaret (v \%) }\end{array}$ & $\begin{array}{l}\text { Specifična } \\
\text { troš. za } 1000 \\
\text { kosov (v EUR) }\end{array}$ & $\begin{array}{l}\text { Proporcio- } \\
\text { nalna troš. od } \\
\text { cene } \\
\text { (v \%) }\end{array}$ & $\begin{array}{l}\text { Specifična } \\
\text { troš. za kg } \\
\text { (v EUR) }\end{array}$ & $\begin{array}{l}\text { Proporcio- } \\
\text { nalna troš. od } \\
\text { cene } \\
\text { (v\%) }\end{array}$ \\
\hline Avstrija & 34,00 & 42,00 & 0 & 13,00 & 0 & 50,00 \\
\hline Bolgarija & 51,64 & 23,00 & 138,05 & 0 & 66,47 & 0 \\
\hline Danska & 90,58 & 21,65 & 26,54 & 10,00 & 87,56 & 0 \\
\hline Finska & 17,50 & 52,00 & 0 & 25,00 & 10,00 & 52,00 \\
\hline Irska & 183,42 & 18,25 & 261,066 & 0 & 220,301 & 0 \\
\hline Italija & 7,6765 & 54,57 & 0 & 23,00 & 0 & 56,00 \\
\hline Nemčija & 90,80 & 21,94 & 14,00 & 1,47 & 41,65 & 14,30 \\
\hline Romunija & 51,49 & 21,00 & 64,00 & 0 & 81,00 & 0 \\
\hline Slovenija & 20,40 & 45,1515 & 0 & 5,00 & 40,00 & 0 \\
\hline $\begin{array}{l}\text { Velika } \\
\text { Britanija }\end{array}$ & 178,60 & 16,50 & 197,93 & 0 & 142,27 & 0 \\
\hline
\end{tabular}

Vir: European Commission (2011, str. 6, 11,12)

\subsection{Trošarine na alkohol in alkoholne pijače}

Trošarina se v skladu s 37. členom ZTro plačuje od piva, vina, drugih fermentiranih pijač, vmesnih pijač ter etilnega alkohola ( $v$ nadaljevanju: alkohol in alkoholne pijače). Vrsta alkohola in alkoholne pijače se določi glede na uvrstitev izdelka $v$ tarifno oznako kombinirane nomenklature carinske tarife in $v$ odvisnosti od vsebnosti alkohola, $\mathrm{ki}$ je volumenski odstotek alkohola (vol.\%) pri temperaturi 20 stopinj Celzija. 


\subsubsection{Stopnje trošarin na alkohol in alkoholne pijače $v$ izbranih državah EU}

Tabela 2: Stopnje trošarine za alkohol in alkoholne pijače $v$ državah EU na dan 1. 7. 2011

\begin{tabular}{|c|c|c|c|c|}
\hline & \multicolumn{4}{|c|}{$\begin{array}{c}\text { STOPNJE TROŠARINE (N EUR) - } \\
\text { Minimalne stopnje po Direktivi 92/84 EGS z dne 19. 10. } 1992\end{array}$} \\
\hline & $\begin{array}{c}\text { Pivo: 0,748 EUR za } \\
\text { stopnjo Plato/hl } \\
\text { oz. 1,87 EUR za 1\% } \\
\text { prostorninske vsebnosti } \\
\text { alkohola/hl* }\end{array}$ & $\begin{array}{c}\text { Stopnje trošarine za } \\
\text { neodvisne male pivovarne } \\
\text { z letno proizvodnjo do } \\
200.000 \mathrm{hl}\end{array}$ & $\begin{array}{c}\text { Vmesne pijače } \\
45 \text { EUR za hektoliter }\end{array}$ & $\begin{array}{l}\text { Etilni alkohol } \\
550 \text { EUR za } \\
\text { hl/100\% }\end{array}$ \\
\hline Država članica & 1. 7. 2011 & 1. 7. 2011 & 1. 7. 2011 & 1. 7.2011 \\
\hline Avstrija & 2,00 & $\begin{array}{l}<12.500 \mathrm{hl}-1,20 \\
<25.000 \mathrm{hl}-1,40 \\
<37.500 \mathrm{hl}-1,60 \\
<=50.000 \mathrm{hl}-1,80\end{array}$ & $\begin{array}{c}\text { mirne }-73,00 \\
\text { peneče }-73,00\end{array}$ & 1000,00 \\
\hline Bolgarija & 0,767 & 0,38 & 46,01 & 562,43 \\
\hline Danska & $6,83^{*}$ & $\begin{array}{c}<=3.700 \mathrm{hl}- \\
\text { izr. po formuli } \\
>3.700<=20.000 \mathrm{hl}- \\
\text { izr. po formuli } \\
>20.000<200.000 \mathrm{hl}- \\
\text { izr. po formuli. }\end{array}$ & $\begin{array}{c}\text { mirne } 15-22 \%- \\
123,45 \\
\text { peneče } 15-22 \%- \\
164,51\end{array}$ & 2012,80 \\
\hline Finska & $26,00^{*}$ & $\begin{array}{l}<=2.000 \mathrm{hl}-13,00^{*} \\
<=30.000 \mathrm{hl}-18,20^{*} \\
<=55.000 \mathrm{hl}-20,80^{*} \\
<=100.000 \mathrm{hl}-23,40^{*}\end{array}$ & $15,22 \%-568,00$ & $\begin{array}{l}>2,8 \%+\text { drugi } \\
3940,00\end{array}$ \\
\hline Irska & $>2,8 \%-15,71^{*}$ & $\begin{array}{l}\text { vračilo } 50 \% \text { trošarine za } \\
\text { proizvodnjo do } 20.000 \mathrm{hl}\end{array}$ & $\begin{array}{c}\text { mirne }>15 \%-380,52 \\
\text { peneče }-524,48\end{array}$ & 3113,00 \\
\hline Italija & 2,35 & & 68,51 & 800,01 \\
\hline Nemčija & 0,787 & $\begin{array}{l}<=5.000 \mathrm{hl}-0,4407 \\
<=10.000 \mathrm{hl}-0,5288 \\
<=20.000 \mathrm{hl}-0,6170 \\
<=40.000 \mathrm{hl}-0,6610\end{array}$ & $>15-22 \%-153,00$ & 1303,00 \\
\hline Romunija & 0,748 & $<=200.000-0,43$ & 165,00 & 750,00 \\
\hline Slovenija & $10,00^{*}$ & & 100,00 & 1000,00 \\
\hline Velika Britanija & $21,40^{*}$ & $\begin{array}{c}<=60.000 \mathrm{hl}-\text { izračun po } \\
\text { posebni formuli }\end{array}$ & $15-22 \%-370,69$ & 2941,44 \\
\hline
\end{tabular}

Vir: European Commission (2011, str. 8-9, 16-17, 19-20)

Pet držav je imelo stopnjo trošarine predpisano glede na prostorninsko vsebnost alkohola $v$ hektolitru piva (podatki so označeni z zvezdico), pet držav pa je imelo stopnjo trošarine predpisano za stopnjo Plato na hektoliter piva. Najnižjo stopnjo trošarine na pivo med državami, ki imajo stopnjo trošarine predpisano za stopnjo Plato na hektoliter piva, sta imeli Romunija in Bolgarija, najvišjo pa Italija in Avstrija. Najnižjo stopnjo trošarine na pivo med državami, ki imajo stopnjo trošarine 
predpisano za $1 \%$ prostorninske vsebnosti alkohola $v$ hektolitru piva, sta imeli Danska in Slovenija, najvišjo pa Finska in Velika Britanija. Znižano stopnjo trošarine za neodvisne male pivovarne $z$ letno proizvodnjo do 200.000 hektolitrov piva je imelo osem držav, dve državi (Italija in Slovenija) pa takšnih olajšav nista imeli. Države imajo olajšave urejene na različne načine. Iz tabele 2 je razvidno tudi, da so najnižjo stopnjo trošarine na vmesne pijače imele Bolgarija, Italija in Avstrija, najvišjo pa Finska, Irska in Velika Britanija. Najnižjo stopnjo trošarine za etilni alkohol so imele Bolgarija, Romunija in Italija, najvišjo pa Finska, Irska in Velika Britanija.

\subsection{Trošarine na energente in električno energijo}

\subsubsection{Stopnje trošarin za energente $v$ izbranih državah članicah EU}

Tabela 3: Stopnje trošarin za plinsko olje za pogonski namen in ogrevanje ter neosvinčeni bencin v državah EU na dan 1. 7. 2011

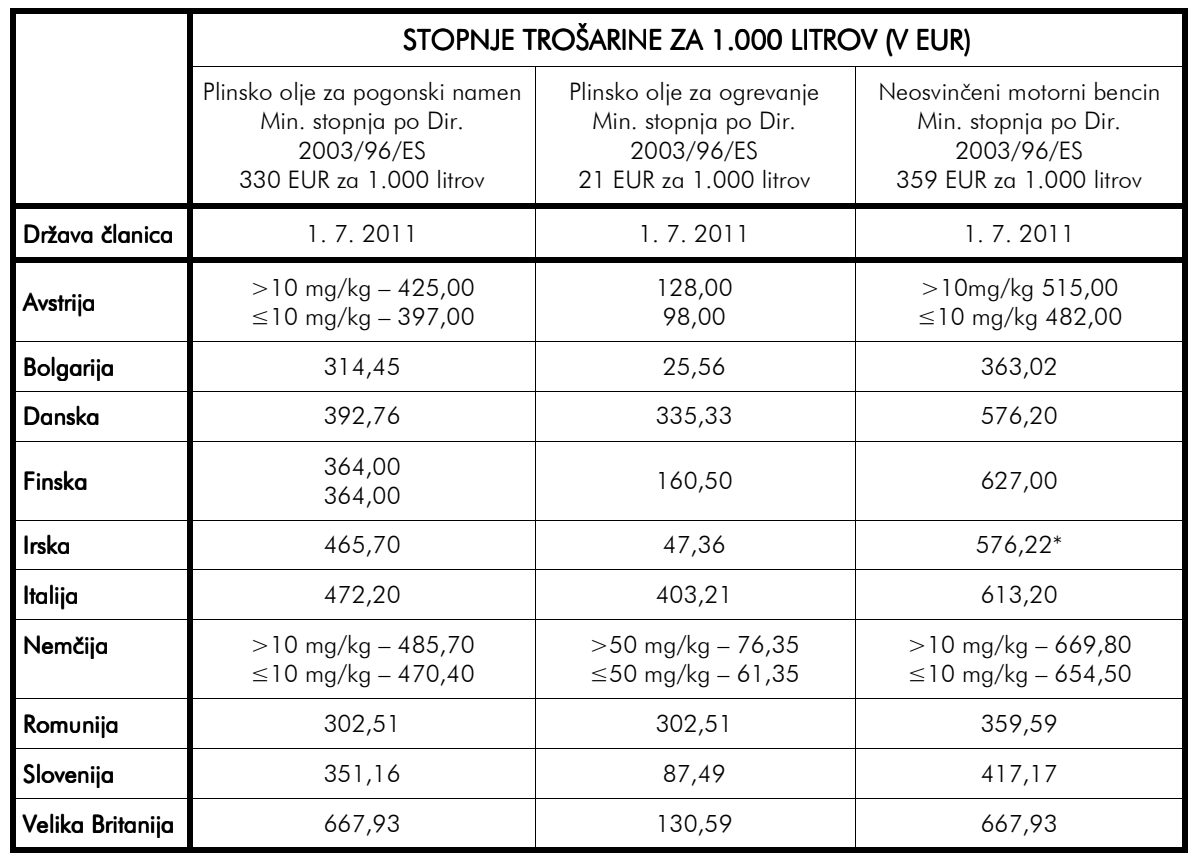

Vir: European Commission (2011, str. 8-10, 13-15)

Dve državi sta imeli predpisano nižjo stopnjo trošarine za plinsko olje za pogonski namen, kot je predpisana z evropsko direktivo, kar je rezulta† pogajanja posameznih držav z Evropsko komisijo. Najnižjo stopnjo trošarine na plinsko olje za pogonski namen so imele Romunija, Bolgarija

144 Uprava, letnik IX, 4/2011 
in Slovenija, najvišjo pa Velika Britanija, Nemčija in Italija. Najnižjo stopnjo trošarine za plinsko olje za ogrevanje (za neposlovno uporabo) so imele Bolgarija, Irska (brez vključene CO2 takse) in Slovenija, najvišjo pa Italija, Danska in Romunija. Iz tabele 3 je razvidno še, da so najnižjo stopnjo trošarine za neosvinčeni motorni bencin imele Romunija, Bolgarija in Slovenija, najvišjo pa Velika Britanija, Nemčija in Finska.

\subsection{Struktura prihodkov, ki jih je vplačala Carinska uprava Republike Slovenije}

Tabela 4: Prihodki, pobrani in vplačani v proračun od carinske uprave, prihodki proračuna ter delež trošarin v prihodkih, pobranih in vplačanih od carinske uprave v obdobju od 1999 do 2010

\begin{tabular}{|l|c|c|c|c|c|}
\hline Leto & $\begin{array}{c}\text { Višina pobranih } \\
\text { dajatev (v EUR) }\end{array}$ & $\begin{array}{c}\text { Indeks } \\
\text { (glede na } \\
\text { leto 1999) }\end{array}$ & $\begin{array}{c}\text { Višina prihodkov } \\
\text { državnega } \\
\text { proračuna } \\
\text { (v EUR) }\end{array}$ & $\begin{array}{c}\text { Delež } \\
\text { vplačanih } \\
\text { sredstev v } \\
\text { državni } \\
\text { proračun (v \%) }\end{array}$ & $\begin{array}{c}\text { Delež } \\
\text { trošarin v } \\
\text { dajatvah } \\
\text { (v \%) }\end{array}$ \\
\hline 1999 & $881.197 .700,48$ & 1,00 & 3.935 .423 .558 & 22,39 & 27,91 \\
\hline 2000 & $1.928 .811 .712,43$ & 2,189 & 4.135 .316 .380 & 46,64 & 27,8 \\
\hline 2001 & $2.273 .286 .844,21$ & 2,580 & 4.776 .242 .618 & 47,60 & 31,48 \\
\hline 2002 & $2.569 .470 .723,34$ & 2,916 & 4.895 .346 .032 & 52,49 & 30,62 \\
\hline 2003 & $3.000 .560 .340,74$ & 3,405 & 5.811 .578 .949 & 51,63 & 27,85 \\
\hline 2004 & $2.328 .654 .335,59$ & 2,643 & 6.323 .186 .288 & 36,83 & 39,56 \\
\hline 2005 & $1.589 .312 .022,53$ & 1,804 & 6.801 .959 .950 & 23,37 & 60,49 \\
\hline 2006 & $1.667 .069 .788,00$ & 1,892 & 7.396 .475 .699 & 22,54 & 57,60 \\
\hline 2007 & $2.006 .610 .535,49$ & 2,277 & 7.799 .943 .931 & 25,73 & 58,2 \\
\hline 2008 & $2.155 .906 .318,59$ & 2,447 & 8.535 .070 .002 & 25,26 & 56,7 \\
\hline 2009 & $2.140 .419 .484,99$ & 2,429 & 7.530 .721 .087 & 28,42 & 67,1 \\
\hline 2010 & $2.365 .730 .199,04$ & 2,685 & 7.549 .556 .129 & 31,34 & 64,3 \\
\hline
\end{tabular}

Vir: Ministrstvo za finance in carinska uprava

Delež vplačanih dajatev je v letih od 1999 do 2003 rastel in je v letu 2002 znašal 52,49 \%, kar pomeni, da je carinska uprava prispevala več kot polovico sredstev $v$ državni proračun. Delež pobranih dajatev se je $v$ letu 2003 zmanjšal na 51,63 \%, potem pa je sledil občuten padec. Slovenija je v EU vstopila 1. 5. 2004, zato je padec $v$ tem letu nekoliko manjši, potem pa sledi večji padec. Največji je bil zabeležen pri DDV ob uvozu, saj trošarina po novem ob uvozu blaga iz drugih članic EU ni več uvozna dajatev. Iz tabele 4 je razvidno tudi to, da se je z vstopom v EU fiskalna pomembnost carinske uprave začela zmanjševati, ob tem pa se je 
$v$ dajatvah, ki jih je pobrala, znatno povečala pomembnost trošarin, saj so te v letu 2009 znašale že 67,1 \%, pred vstopom v EU pa niihov odstotek znašal okoli 30 \%. Pri podatkih o višini pobranih dajatev so podani bruto zneski vplačanih dajatev, prav tako pa so pri izračunu upoštevani bruto zneski vplačanih oziroma pobranih trošarin.

\section{Trošarinski izdelki v Republiki Hrvaški}

Hrvaška je od leta 1994 dalje postopoma uvedla devet trošarin, in sicer na kavo, naftne derivate, alkohol in alkoholne pijače, tobačne izdelke, pivo, brezalkoholne pijače, osebne avtomobile, ostala motorna vozila, plovila in letala, luksuzne izdelke ter premije zavarovanja avtomobilske odgovornosti (Kuliš, 2005, str. 11).

Hrvaški sabor je 3. julija 2009 sprejel Zakon o trošarinama (v nadaljevanju: ZOT), ki se je začel uporabljati s 1.1.2010, razen nekaterih določb ZOT, ki bodo stopile v veljavo ob vstopu Hrvaške v EU. Z ZOT je trošarinski sistem $\vee$ Hrvaški usklajen s trošarinskim sistemom EU na področju obdavčevanja energentov, alkohola in alkoholnih pijač ter tobačnih izdelkov. ZOT je usklajen s trošarinskimi sistemi v državah članicah EU ter s t.i. horizontalno direktivo 92/12/EGS. ZOT ne obravnava neusklajenih (neharmoniziranih) trošarin. Nijhovo obdavčevanje urejajo posamični zakoni, ki niso del pravnega sistema EU. Tretji odstavek 3. člena Direktive sveta 92/12/EGS namreč določa, da lahko države članice EU uvedejo ter obdržijo davke, ki se plačujejo na druge izdelke (Marinović, 2009, str. 41).

\subsection{Trošarine na brezalkoholne pijače}

Za brezalkoholne pijače se smatrajo osvežilne brezalkoholne pijače iz sadnega soka, sadnih baz, rastlinskih ekstraktov, žitaric, sirotke, umetne in nizko energetske osvežilne brezalkoholne pijače ter sirupi, ki so namenjeni za proizvodnjo ali pripravo brezalkoholnih pijač. Med brezalkoholne pijače se po ZOT ne uvrščajo domače in uvožene naravne mineralne gazirane in negazirane vode, namizne vode in $100 \%$ naravni sokovi, voda za pitje ter domače in uvožene naravne vode, ki se dostavljajo v paketih. Posebni davek na brezalkoholne pijače se plača za hektoliter proizvedene ali uvožene brezalkoholne pijače. Če se uvažajo ali nabavljajo sirupi, praški in pastile za osvežilne brezalkoholne pijače, se posebni davek plača glede na količino osvežilne brezalkoholne pijače, ki se lahko dobi z njihovim raztapljanjem $v$ vodi, glede na priložena

146 Uprava, letnik IX, 4/2011 
navodila. Posebni davek se plača v višini 40,00 kun po hektolitru domače ali uvožene brezalkoholne pijače (Zakon o posebnom porezu na bezalkoholna pića, člen 3, 6).

Davčna in carinska uprava sta na podlagi predlogov davčnih zavezancev in nijhovih združeni nekajkrat predlagala, da se zakon ukine. Prihodki od trošarin na brezalkoholne pijače so namreč majhna postavka $\checkmark$ strukturi prihodkov državnega proračuna. Pri tem je treba izpostaviti tudi dejstvo, da nobena država članica nima trošarine na brezalkoholne pijače (Marinović, 2005, str. 23).

\subsection{Trošarine na kavo}

Za kavo se šteje surova kava, vključno kava brez kofeina, pražena kava $v$ zrnju ali mleta, vključno s kavo brez kofeina, kavne luske in jedrca ter ostali izdelki iz kave (v nadaljevanju: kava). Čokolada ter izdelki, ki so podobni čokoladi, kremni izdelki, bomboni, pekarski izdelki, praški za pudinge in kreme ter drugi podobni izdelki z dodatkom kave se ne smatrajo za kavo.

Posebni davek na kavo se plača za en kilogram neto teže kave, in sicer:

- za surovo kavo (vključno s kavo brez kofeina) v višini 5,00 kun,

- za praženo kavo $v$ zrnju ali mleto (vključno s kavo brez kofeina) v višini 12,00 kun,

- za kavne luske in jedrca v višini 15,00 kun,

- za ostale proizvode od kave v višini 20,00 kun.

Kava, ki je $v$ prometu na carinskem področju Hrvaške, mora biti označena z ustrezno znamkico Ministrstva za finance Republike Hrvaške (Zakon o posebnom porezu na kavu, člen 3, 6, 9).

\subsection{Trošarine na luksuzne predmete}

Predmet obdavčenja so luksuzni izdelki, med katere spadajo izdelki, kot so nakit in sorodni izdelki, ure, obleka in obutev iz krzna in kože plazilcev, pirotehnični izdelki za ognjemete, orožje ter ostali izdelki iz slonovine, želvovine, koralov ter vžigalniki za cigarete. Davčna osnova za plačilo posebnega davka je prodajna vrednost (prodajna cena je cena brez DDV) in znaša 30 \% od davčne osnove (Zakon o posebnom porezu na luksuzne proizvode, člen 2, 5, 6). 


\subsection{Trošarine na osebna vozila, druga motorna vozila, plovila in letala}

Predmet obdavčenja so določeni osebni avtomobili, druga motorna vozila, plovila in letala, ki se uvažajo, proizvajajo ali prodajajo na Hrvaškem. Predmet obdavčenja je promet ali drugi način pridobitve uporabe osebnih avtomobilov, drugih motornih vozil, plovil in letal.

Davčna osnova posebnega davka na promet rabljenih osebnih vozil, drugih motornih vozil, plovil in letal je tržna vrednost $v$ trenutku nastanka davčne obveznosti, ki se ugotavlja na podlagi dokumentov o pridobitvi. Davčna uprava preverja tržno vrednost, ki je izkazana $v$ dokumentih o pridobitvi. Če ugotovi, da ta ni izkazana realno, potem davčno osnovo ugotovi na podlagi cenitve. Posebni davek na osebne avtomobile in motorna kolesa, ki se ne smatrajo za nova, se poveča za $50 \%$, za osebne avtomobile s prostornino preko 1.600 kubičnih centimetrov in motorna kolesa s prostornino preko 250 kubičnih centimetrov pa za $100 \%$, pri osebnih avtomobilih $z$ rotacijskim gibanjem batov in tistih, ki se ne smatrajo za nova, pa se poveča za $50 \%$. Posebni davek se ne plača na osebne avtomobile in motorje, ki jih poganjajo električni motorji. Posebni davek na promet rabljenih avtomobilov, drugih motornih vozil, plovil in letal se plača po stopnii 5 \% (Zakon o posebnim porezima na osobne automobile, ostala motorna vozila, plovila i zrakoplove, člen 1, 3, 5, 6).

Osebni avtomobili in motorna kolesa, sproščeni $v$ prost promet in registrirani v Republiki Hrvaški, so obremenjeni s številnimi dajatvami. Pri uvozu so predmet davka na dodano vrednost, pri osebnih vozilih in motornih kolesih pa je treba ob registraciji plačati DDV, letni davek na cestna motorna vozila, letno nadomestilo za uporabo javnih cest, posebno nadomestilo za okolisko dajatev za vozila na motorni pogon, davek na premije zavarovanja od avtomobilske odgovornosti in premije na kasko zavarovanje cestnih vozil (Kursar Hajnić, 2010, str. 73).

\section{Predlogi sprememb}

a) V Sloveniji bi morali zmanjšati trošarine na pivo. Slovenija namreč spada med izbrane države članice EU z najvišjo stopnjo trošarine na pivo, saj je ta več kot petkrat višja, kot je najnižja stopnja trošarine, predpisana z Direktivo Sveta 92/84/EGS z dne 19. 10. 1992 (v nadaljevanju: Direktiva). Slovenija je tudi v skupini dveh držav, ki med izbranimi državami članicami EU nimata znižane stopnje trošarine 
za neodvisne male pivovarne z letno proizvodnjo do 200.000 hektolitrov piva, kot jo dopušča Direktiva. Zaradi izenačitve velikih in malih proizvajalcev piva pri nas male pivovarne (pivnice) zelo težko konkurirajo velikim proizvajalcem. Spričo teh navedenih dejstev bi morala Slovenija razmisliti o uvedbi olajšave za male pivovarne.

b) Slovenija bi morala uvesti trošarine na nekatere nove izdelke. Uvedla jih je samo na harmonizirane trošarinske izdelke, Hrvaška pa je poleg trošarin na harmonizirane trošarinske izdelke uvedla trošarine še na neharmonizirane trošarinske izdelke (na kavo, brezalkoholne pijače, osebne avtomobile, druga motorna vozila in zrakoplove, luksuzne izdelke in premije avtomobilskega zavarovanja). Slovenija bi lahko po vzoru Hrvaške uvedla trošarino na kavo. Gre namreč za izdelek široke potrošnje, ki nima nadomestkov, uvedba te trošarine pa ne bi vplivala na rast cen drugih izdelkov in storitev, kot se to lahko zgodi pri višanju trošarin na energente, predvsem na plinsko olje za pogonski namen. Po vzoru Hrvaške lahko uvede trošarine tudi na druge neharmonizirane trošarinske izdelke. Kljub dejstvu, da je trošarine dokaj lahko pobirati, pa bi bilo treba pred uvedbo trošarin na nove trošarinske izdelke opraviti temeljito analizo o tem, na katere trošarinske izdelke bi bilo trošarine smiselno uvesti, predvsem z vidika, koliko sredstev bi te prinesle $v$ državni proračun. Zagotovo pa $v$ Sloveniji ne bi bilo smiselno uvesti trošarine na brezalkoholne pijače. Uvedba te trošarine bi namreč vplivala na povečanje cen brezalkoholnih pijač, kar bi lahko posledično vplivalo na večjo porabo alkoholnih pijač (predvsem pri mladih).

c) V Sloveniij bi morali nekatere trošarine zvišati. Država se sooča s povečanjem cen surove nafte na svetovnem trgu, kar posledično vpliva na rast cen naftnih derivatov. Cene naftnih derivatov se pogosto spreminjajo in so trenutno zelo visoke ne glede na relativno nizko stopnjo trošarine za plinsko olje za pogonski namen. Slovenija je imela tudi $v$ preteklosti dokaj visoke cene plinskega olja za pogonski namen, vendar pri tem tudi bistveno višjo stopnjo trošarine. $\checkmark$ sedanjih razmerah je vlada cene plinskega olja za pogonski namen obvladovala predvsem z nižanjem trošarin, kar pomeni tudi nižje prihodke. Po podatkih Evropske komisije na dan 1.7.2011 je Slovenija sodila med izbrane države članice EU z najnižjo stopnjo trošarine na plinsko olje za pogonski namen. Če bi se vlada odločila za zvišanje cen plinskega olja za pogonski namen, je vprašanje, kako 
bi to vplivalo na porabo plinskega olja za pogonski namen. Zagotovo pa bi to pomenilo povečanje prevoznih stroškov, možen je tudi vpliv na povečanje cen drugih izdelkov. Zvišanje cene plinskega olja ob nespremenjeni trošarini pomeni tudi veliko nevarnost, da bi se tovorna vozila, ki so največji porabnik plinskega olja za pogonski namen, z gorivom začela oskrbovati predvsem $v$ sosednjih državah in ne $v$ Sloveniji (predvsem tovorna vozila, ki so $v$ tranzitu skozi Sloveniio).

Če bi se vlada $v$ dani situaciji odločila za zvišanje trošarin na trošarinske izdelke, bi morala zvišati trošarine na tobačne izdelke ter alkohol in alkoholne pijače. Po podatkih Evropske komisije sodi Slovenija med izbranimi državami članicami EU med države z nižjo stopnjo specifične trošarine in višjo stopnjo proporcionalne trošarine na cigarete ter med države, ki imajo na cigare in cigarilose predpisano samo proporcionalno stopnjo trošarine, ki je na ravni minimalne trošarine, predpisane z Direktivo. Za drobno rezani tobak ima Slovenija predpisano samo specifično stopnjo trošarine, ki je med najnižjimi med izbranimi državami članicami EU.

Po podatkih Evropske komisije sodi Slovenija med izbranimi državami članicami EU med države z najnižjo stopnjo trošarine za etilni alkohol in države z nižjo stopnjo trošarine za vmesne pijače. Zvišanje trošarin pri tobačnih izdelkih in etilnem alkoholu ter vmesnih pijačah bi zagotovo pripomoglo k povečanju prihodkov za državni proračun, ker gre za izdelke, za katere ne obstajajo nadomestki, povzročajo pa tudi odvisnost. Iz navedenih razlogov je tudi manjša možnost, da bi se zaradi povečanja cen zmanjšala njihova poraba. Razlog za povečanje trošarin za omenjene izdelke pa je tudi zdravstveni vidik.

d) V Slovenija bi morali pred povečanjem stopeni trošarin ali ob uvedbi trošarin na nove trošarinske izdelke opraviti temeliito analizo o tem, kot meni Kuliš (Kuliš, 2010, str. 3), ali bi k polnjenju proračuna bistveno boli prispevali prihodki od tihotaplienja in nelegalne trgovine izdelkov, od katerih se plačuje trošarina, identificiranje davčnih dolžnikov ter izterjava neplačanih davčnih obveznosti.

\section{Zaključek}

Z vstopom Slovenije v EU se je zmanjšal delež vplačanih dajatev, ki jih carinska uprava vplača $v$ državni proračun, hkrati pa so trošarine postale najpomembnejša dajatev, ki jo pobere carinska uprava. Pri 
primerjavi stopenj trošarin na trošarinske izdelke med izbranimi državami članicami EU lahko ugotovimo, da Slovenija sodi med države, ki ima kar nekaj možnosti za zvišanje trošarin, saj po podatkih Evropske komisije sodi med države z nižjo specifično trošarino na cigarete (proporcionalna trošarina na cigarete je med višjimi), in države, ki je na cigarilose in cigare uvedla samo proporcionalno stopnjo trošarine, ki je med najnižjimi, ter med države z najnižjo stopnjo proporcionalno stopnje trošarine za drobno rezani tobak. Ravno tako Slovenija sodi med države z nižjo stopnjo trošarine za etilni alkohol in vmesne pijače. Slovenija sodi med države z najvišjo stopnjo trošarine na pivo, zaradi česar bi morala vlada razmisliti o tem, da bi uvedla olajšave za neodvisne male pivovarne z letno proizvodnjo do 200.000 hl. Slovenija sodi tudi med države članice EU, ki ni uvedla trošarine na neharmonizirane trošarinske izdelke.

$\checkmark$ primeru zvišanja trošarin $\vee$ Sloveniji bi bilo treba zvišati predvsem trošarine na tobačne izdelke ter alkohol in alkoholne pijače. Zvišanje trošarin na omenjene izdelke bi namreč prispevalo $k$ povečanju proračunskih sredstev, razlog za zvišanje pa je tudi zdravstveni vidik. Slovenija lahko sledi zgledu Republike Hrvaške in uvede trošarine na nekatere neharmonizirane trošarinske izdelke.

Vlada lahko stopnje trošarine na tobačne izdelke ter alkohol in alkoholne pijače zviša sama, saj ima v Zakonu o trošarinah zakonsko podlago, da veljavne stopnje trošarin zviša ali zniža do 50 \%. Če pa bi se vlada odločila za uvedbo trošarin na neharmonizirane trošarinske izdelke, bi se morali predlogi zakonodaje obravnavati $\vee$ rednem zakonodajnem postopku. 
Mag. Ivan Kopina je leta 1997 zaključil višješsolski študij na Višji upravni šoli, leta 1998 visokošolski študij na Visoki upravni šoli, leta 2006 specialistični študij na Fakulteti za upravo, v septembru leta 2011 pa je na isti fakulteti zaključil magistrski študij. Od 1. 2. 2000 je zaposlen kot višji carinski svetovalec inšpektor - specialist v Carinskem uradu Ljubljana, kjer dela na področju trošarin.

Dr. Stanka Setnikar Cankar je redna profesorica ekonomike javnega sektoria in dekanja Fakultete za upravo Univerze v Ljubljani. Je avtorica številnih člankov in knjig na temo ekonomike javnega sektorja in glavna urednica revije "Uprava". Bila je članica upravnega odbora NISPACee, je članica programskega odbora letne konference Dnevi slovenske uprave, članica IIASIA, EGPA, itd. Uspešno vodi razne raziskovalne projekte in sodeluje pri njih, zlasti na področju reform $v$ javnem sektorju, reform $v$ javnem sektoriu $v$ zdravstvu, vrednotenja uspešnosti $v$ javni upravi in čezmejnega sodelovanja med Slovenijo, Avstrijo in Italijo.

152 Uprava, letnik IX, 4/2011 


\section{Literatura in viri}

\section{Literatura}

- Adams, C. (2006). Za dobro i zlo: Utjecaj poreza na kretanje civilizacije. Zagreb: Institut za javne financije.

- Cnossen, S. (2005). Theory and Practice of Excise Taxation: Smoking, Drinking, Gambling, Polluting and Driving. Oxford: Oxford University Press.

- Hitiris, T. (2003). European Union Economics - 5th Edition. Dorset: Dorset Press.

- Kuliš, D. (2005). Plaćamo li europske trošarine. Zagreb: Institut za javne financije.

- Kuliš, D. (2007). Javne financije u Hrvatskoj, treće promijenjeno izdanje. V: Ott, K. (ur.): Porez na potrošnju. Zagreb: Institut za javne financije.

- Kursar Hajnić, A. (2010), Oporezivanje novih i rabljenih osobnih automobila i motocikla. Carinski viesnik XIX(7), 73-81.

- Marinović, Ž. (2005). Porezni tretman bezalkoholnih pića. Carinski vjesnik XIV(4), 23-33.

- Marinović, Ž. (2009). Novi zakon o trošarinama. Carinski vjesnikXVIII(9), $41-65$.

- $\quad$ Preece, R. (2008). Key Controls in the Administration of Excise Duties. V: World Customs Journa/ (73-92). Canberra: International Network of Customs Universities.

\section{Spletni viri}

- Carinska uprava RS (2005). Poročilo o delu carinske službe v letu 2004. Pridoblieno 1. 3. 2011 , s: http://www.carina.gov.si/fileadmin/ curs.gov.si/pageuploads/Katalog_inf_javn_znac/Dokumenti/letno_porocilo_ 2004.pdf.

- Carinska uprava RS (2011). V proračun RS vplačane obvezne dajatve, ki so v pristojnosti CURS za obdobje od 1999 do 2010. Pridoblieno 1. 3. 2011, s: http://intra-adm.curs.sigov.si/index.php? $d=17428$.

- European Commission (201 1a). Excise Duty Tables Part I - Alcoholic Beverages. REF 1.033. Pridobljeno 7. 8. 2011 , s: http://ec.europa.eu/taxation_customs/resources/documents/taxation/excise duties/alcoholic_beverages/rates/excise_duties-part_i_alcohol_en.pdf.

- European Commission (201 1 b). Excise Duty Tables Part // - Energy Products and Elektricity. REF 1033. Pridobljeno 8. 7. 2011 , s: 
http://ec.europa.eu/taxation_customs/resources/documents/taxation/excise_ duties/energy_products/rates/excise_duties-part_ii_energy_products_en.pdf.

- European Commission (2011 c). Excise Duty Tables Part III - Manufactured Tobacco. REF 1.033. Pridobljeno 7. 8. 2011 , s:

http://ec.europa.eu/taxation_customs/taxation/excise_duties/tobacco_produ $\mathrm{cts} /$ rates/index_en.htm.

- Ministrstvo za finance (2011). Bilten javnih financ. Serija podatkov - Državni proračun 1992-2011. Pridoblieno 1. 3. 2011 , s:

http://www.mf.gov.si/si/delovna_podrocja/tekoca_gibanja_v_javnih_financa h/bilten_javnih_financ/.

\section{Pravni viri}

- Pravilnik o izvajanju Zakona o trošarinah. Uradni list RS, št. 49/04, 47/05, 17/07 (18/07 popr.), 26/10.

- Zakon o posebnim porezima na osobne automobile, ostala motorna vozila, plovila i zrakoplove. Narodne novine, broi 139/97, 105/99, 55/00, 127/00, 107/01, 95/04, 94/09, 21/10.

- Zakon o posebnom porezu na bezalkoholna pića. Narodne novine, broi 136/02 - pročišćeni tekst.

- Zakon po posebnom porezu na kavu. Narodne novine, br. 31/11.

- Zakon o posebnom porezu na luksuzne proizvode. Narodne novine, br. 136/02 - pročišćeni tekst.

- Zakon o porezu na premije osiguranja od automobilske odgovornosti i premije kasko osiguranja cestovnih vozila. Narodne novine, br. 150/02.

- Zakon o trošarinah. Uradni list RS, št. 97/10 - uradno prečiščeno besedilo. 


\title{
PRODUCTS SUBJECT TO EXCISE DUTY IN SLOVENIA AND COMPARISONS WITH OTHER COUNTRIES
}

\author{
Keywords: excise duties, harmonised excisable products, non- \\ harmonised excisable products, excise duty rate, excise \\ system, increase of excise duty rate
}

The current excise system in Slovenia came into force on 1 July 1999 and covers the specific regime to control trade in and production of excisable goods and the collection of excise duties. Excise procedures fall under the auspices of the Customs Administration of the Republic of Slovenia (Customs Administration) and are implemented by the excise departments of its customs offices. Following Slovenia's entry into the EU on 1 May 2004 the system was adapted to ensure full compliance with EU rules on harmonised excise duties. The excise system is governed by the Excise Duty Act (official Slovenian abbreviation: ZTro) and its implementing regulations and a number of EU regulations that apply directly. Slovenia's 2004 EU entry also had an impact on the collection of duties. That year the Customs Administration assumed the role of collecting the Community's own funds. Their accounting records are a combination of revenues charged and paid, in contrast to mandatory duties, which form part of Slovenia's budget revenues, which are only recorded once paid. Member states retain 25\% of the Communities traditional own funds to cover the cost of collecting these duties.

Slovenia's EU entry increased the importance of excise duties, making them the most important duty paid into the national budget by the Customs Administration. Data on collected duties paid into the national budget from 1999 to 2009 indicates that the proportion of excise duties as a total of all duties ranged from $27 \%$ to $29.56 \%$ between 1999 and 2004 (Slovenia joined the EU on 1 May 2004) and from 56.7\% to 67.1\% from 2005 to 2009. This confirms in full the thesis that excise duties have become the most significant duty paid into the national budget by the Customs Administration since Slovenia's EU entry.

According to Commission data, Slovenia has one of the highest rates of duty on beer in the EU, which is five times higher than the lowest excise 
duty rate prescribed in Council Directive 92/84/EEC of 19 October 1992. Slovenia is also one of the few EU member states that does not have a lower level of excise duty for small independent breweries with an annual production of 200000 hectolitres of beer or less.

In addition to excise duties on harmonised excisable products, Croatia has also introduced excise duties on "non-harmonised" products, imposing duties on coffee, non-alcoholic drinks, cars, other motor vehicles and aeroplanes, luxury products and car insurance premiums. Slovenia could follow Croatia and introduce excise duty at least on coffee. Coffee is a widely consumed product for which there is no substitute product, and making it subject to excise duty would not lead to an increase in the price of other products and services, as could happen by increasing excise duties on fuel, particularly on diesel. Of course, Slovenia could also follow Croatia in introducing excise duties on other nonharmonised excisable products. Despite the fact that excise duty is relatively easy to collect, before being imposed on new products there would be a need for a basic analysis of which excisable products it would be rational to introduce duties on, primarily in terms of the amount of funds they would add to the national budget. It would definitely not be rational for Slovenia to introduce excise duties on non-alcoholic drinks. This would lead to an increase in the price of non-alcoholic drinks, which would lead to increased consumption of alcoholic drinks, particularly among young people.

Slovenia faces the issue of increasing prices of crude oil on the global market, which has an effect on the price of oil derivatives. In the past Slovenia had relatively high prices for diesel, including a significantly higher level of excise duty. In current conditions the Government has mainly managed diesel prices by reducing excise duties, which naturally led to lower excise revenues. According to Commission data, on 1 July 2011 Slovenia had one of the lowest levels of excise duty on diesel in the EU. If the Government decided in current conditions to increase diesel prices, it would definitely lead to lower consumption of diesel. Increasing the price of diesel would increase transport costs and could also increase the price of other products. Rising diesel prices while excise duty remains the same also risks goods vehicle users, the largest consumers of diesel, starting to source fuel in neighbouring countries instead of in Slovenia (particularly goods vehicles in transit through Slovenia). At present if the Government decided to increase excise duties on excisable products, it

156 Uprava, letnik IX, 4/2011 
would mainly have to increase excise duties on tobacco products and alcohol and alcoholic drinks. Commission data indicates that on 1 July 2011 Slovenia had one of the EU's lower levels of specific excise duty and a higher level of proportional excise duty on cigarettes and is one of the member states with only proportional excise duty on cigars and cigarillos, which is at the lowest level prescribed by the Directive. Slovenia only prescribes specific excise duty for fine-cut tobacco, which is among the lowest in the EU. According to Commission data, Slovenia has one of the lowest levels of excise duty on ethyl alcohol and a lower level of excise duty on "intermediate drinks" (1.2\% to $22 \%$ alcohol content). Increasing excise duties on tobacco products and ethyl alcohol and intermediate drinks would definitely increase budget revenues, since they are products for which there are no substitutes and furthermore they cause dependency. For these reasons there is also a lower possibility of consumption falling due to prices increasing. The health aspect is part of the reason for increasing excise duties on these products. These facts confirm the second thesis that Slovenia should change its excise duty system to bring it into line with select EU states by: a) reducing some excise duties; b) introducing excise duties to some new products, and c) increasing some excise duties.

Before increasing excise duty rates or introducing excise duties to new products, Slovenia should carry out a thorough analysis on whether greater control of smuggling and illegal trade in excisable products would contribute significantly more revenue to the budget, or if more effort should be focused on identifying tax debtors and recovering unpaid taxes.

The Government could raise excise duties on tobacco products and alcohol and alcoholic drinks only, since the Excise Duties Act provides a legal basis for raising excise duties to $50 \%$. If the Government decides to introduce excise duties on non-harmonised excisable products, it will have to launch legislative procedures to amend the law. 